\title{
In vitro study of uptake and synthesis of creatine and its precursors by cerebellar granule cells and astrocytes suggests some hypotheses on the physiopathology of the inherited disorders of creatine metabolism
}

Claudia Carducci ${ }^{1,6}$, Carla Carducci ${ }^{1}$, Silvia Santagata ${ }^{1}$, Enrico Adriano ${ }^{2}$, Cristiana Artiola ${ }^{1}$, Stefano Thellung ${ }^{3}$, Elena Gatta ${ }^{4}$, Mauro Robello ${ }^{4}$, Tullio Florio ${ }^{4}$, Italo Antonozzi ${ }^{1}$, Vincenzo Leuzzi ${ }^{{ }^{*}+}$ and Maurizio Balestrino ${ }^{2 \dagger}$

\begin{abstract}
Background: The discovery of the inherited disorders of creatine $(\mathrm{Cr})$ synthesis and transport in the last few years disclosed the importance of blood $\mathrm{Cr}$ supply for the normal functioning of the brain. These putatively rare diseases share a common pathogenetic mechanism (the depletion of brain $\mathrm{Cr}$ ) and similar phenotypes characterized by mental retardation, language disturbances, seizures and movement disorders. In the effort to improve our knowledge on the mechanisms regulating $\mathrm{Cr}$ pool inside the nervous tissue, $\mathrm{Cr}$ transport and synthesis and related gene transcripts were explored in primary cultures of rat cerebellar granule cells and astrocytes.

Methods: $\mathrm{Cr}$ uptake and synthesis were explored in vitro by incubating monotypic primary cultures of rat type I astrocytes and cerebellar granule cells with: a) $D_{3}$-Creatine $\left(D_{3} C r\right)$ and D3Cr plus $\beta$-guanidinopropionate (GPA, an inhibitor of $\mathrm{Cr}$ transporter), and b) labelled precursors of Guanidinoacetate (GAA) and $\mathrm{Cr}$ (Arginine, Arg; Glycine, Gly). Intracellular D3Cr and labelled GAA and $\mathrm{Cr}$ were assessed by ESI-MS/MS. Creatine transporter (CT1), L-arginine: glycine amidinotransferase (AGAT), and S-adenosylmethionine:guanidinoacetate N-methyltransferase (GAMT) gene expression was assessed in the same cells by real time PCR.

Results: D3Cr signal was extremely high in cells incubated with this isotope (labelled/unlabelled Cr ratio reached about 10 and 122, respectively in cerebellar granule cells and astrocytes) and was reduced by GPA. Labelled Arg and Gly were taken up by the cells and incorporated in GAA, whose concentration paralleled that of these precursors both in the extracellular medium and inside the cells (astrocytes). In contrast, the increase of labelled $\mathrm{Cr}$ was relatively much more limited since labelled $\mathrm{Cr}$ after precursors' supplementation did not exceed 2,7\% (cerebellar granule cells) and 21\% (astrocytes) of unlabelled Cr. Finally, AGAT, GAMT and SLC6A8 were expressed in both kind of cells.

Conclusions: Our results confirm that both neurons and astrocytes have the capability to synthesize and uptake $\mathrm{Cr}$, and suggest that at least in vitro intracellular $\mathrm{Cr}$ can increase to a much greater extent through uptake than through de novo synthesis. Our results are compatible with the clinical observations that when the Cr transporter is defective, intracellular $\mathrm{Cr}$ is absent despite the brain should be able to synthesize it. Further research is needed to fully understand to what extent our results reflect the in vivo situation.
\end{abstract}

\footnotetext{
* Correspondence: vincenzo.leuzzi@uniroma1.it

† Contributed equally

${ }^{5}$ Dept of Child Neurology and Psychiatry, La Sapienza Università di Roma, Via

dei Sabelli 108, Rome 00185, Italy

Full list of author information is available at the end of the article
}

\section{Ciomed Central}

(c) 2012 Carducci et al; licensee BioMed Central Ltd. This is an Open Access article distributed under the terms of the Creative Commons Attribution License (http://creativecommons.org/licenses/by/2.0), which permits unrestricted use, distribution, and reproduction in any medium, provided the original work is properly cited. 
Keywords: L-arginine:glycine amidinotransferase (AGAT), Creatine transporter (CT1), S-adenosylmethionine: guanidinoacetate N-methyltransferase (GAMT), Energetic metabolism in CNS, Mass spectrometry, Creatine transporter gene (SLC6A8)

\section{Background}

The discovery of the inherited disorders of Cr metabolism has significantly improved the knowledge on the role of creatine $(\mathrm{Cr})$ in the human brain energetic metabolism $[1,2]$ through the observation of the clinical consequence of $\mathrm{Cr}$ deficiency. These putatively rare diseases are due either to defects of the enzymes devoted to $\mathrm{Cr}$ synthesis (L-arginine:glycine amidinotransferase (AGAT, EC 2.1.4.1) [3] and S-adenosylmethionine:guanidinoacetate N-methyltransferase (GAMT, EC 2.1.1.2) [4]) - or to defects of the Cr transporter (CT1) $[5,6]$. They all share a common pathogenetic mechanism (the depletion of brain $\mathrm{Cr}$ ) and similar phenotypes characterized by mental retardation, language disturbances, seizures and movement disorders. The clinical symptoms in AGAT and GAMT deficiencies are partially reversed by oral $\mathrm{Cr}$ supplementation $[7,8]$, and possibly prevented by an early onset treatment $[9,10]$, which also restores almost totally the brain $\mathrm{Cr}$ signal [11]. On the contrary, no effective treatment is available for the defect of CT1: while the supplementation of the precursors of $\mathrm{Cr}$, Arginine (Arg) and Glycine (Gly), restores the $\mathrm{Cr}$ synthesis in peripheral cells in vitro [12], it results in only a mild clinical improvement with scarce [13] or absent [14] increase of brain $\mathrm{Cr}$ signal in vivo. So these rare metabolic disorders disclosed the importance of blood Cr supply for the normal functioning of the brain, even though AGAT and GAMT are widely expressed in the nervous tissue [15] where $\mathrm{Cr}$ synthesis certainly occurs $[16,17]$.

It has been hypothesized that in the absence of CT1, neurons can not take up glial-synthesized $\mathrm{Cr}$ or guanidinoacetate (GAA), so suggesting a glia-neuron interplay in brain $\mathrm{Cr}$ homeostasis [18]. According to this model, we would expect a different distribution of the components involved in $\mathrm{Cr}$ metabolism (transport and synthesis) in neurons and glial cells. In the effort to improve our knowledge on the mechanisms regulating $\mathrm{Cr}$ pool inside the nervous tissue, $\mathrm{Cr}$ synthesis was explored in primary cultures of rat cerebellar granule cells and astrocytes by using Arg and Gly labelled by stable isotopes. Since these compounds are substrates of AGAT (Arg and Gly) and GAMT (GAA), the detection of the labelled products makes it possible to speculate on the distribution of these enzymes in different cells. Moreover, the role of CT1 was tested by incubating cerebellar granule cells and astrocytes with labelled $\mathrm{Cr}$ in the presence and absence of guanidinopropionate (GPA), a specific inhibitor of CT1. Finally CT1 (SLC6A8), GAMT and AGAT gene expression was investigated by the identification and quantification of their transcripts in the same kind of nervous cells in comparison with several other tissues.

\section{Methods}

\section{Chemicals and reagents}

$\mathrm{D}_{3}$-Creatine (D3Cr) was purchased from CDN isotopes (Quebec, Canada). ${ }^{13} \mathrm{C}_{2}$-Guanidinoacetic acid $\left(\left[1,2-{ }^{13} \mathrm{C}_{2}\right]\right.$ GAA) was purchased from Dr. Herman J. ten Brink (Amsterdam, Netherlands). L-[guanido- ${ }^{15} \mathrm{~N}_{2}$ ]arginine: $\mathrm{HCl}$ $\left(\left[{ }^{15} \mathrm{~N}_{2}\right] \mathrm{Arg}\right.$ ) and $\left[{ }^{13} \mathrm{C}_{2},{ }^{15} \mathrm{~N}\right]$ glycine $\left(\left[{ }^{13} \mathrm{C}_{2},{ }^{15} \mathrm{~N}\right]\right.$ Gly) were obtained from Cambridge Isotopes Laboratories Inc. (Massachusetts, USA). GPA, Gly, Arg, GAA, and Cr were obtained from Sigma-Aldrich (St Luis, MO, USA). HPLC grade methanol and formic acid were obtained from Merck (Darmstadt, Germany). $3 \mathrm{~N} \mathrm{HCl}$ in n-butanol solution was purchased from Regis Technologies Inc (Morton Grave, USA). All solutions were prepared using highly purified water produced by a Milli-RO/Milli-Q system (Millipore, Bedford, Ma, USA). Centricone filters were obtained from Millipore (Millipore, Bedford, Ma, USA).

Wistar rats were obtained from Harlan Italy, S. Pietro al Natisone Udine. Twenty $\mathrm{mm}$ poly-l-lysine-coated glass coverslips were obtained from Warner Instruments LLC (Hamden, CT USA). Basal Eagle's culture medium, fetal calf serum, gentamicin and cytosine arabinoside were obtained from Sigma Aldrich (St Luis, MO, USA). PBS containing trypsin, bovine serum albumin, DMEM, fetal bovin serum, penicillin/streptomycin, L-glutamine were obtained from Euroclone (Pero - Milano Italy).

\section{Rat cell culture}

Cerebellar granule cells were prepared from 8-day-old Wistar rats as previously described [19]. The cells were plated at a density of $1 \times 10^{6}$ per dish on $20 \mathrm{~mm}$ poly-llysine-coated glass coverslips and maintained in Basal Eagle's culture medium, containing $10 \%$ fetal calf serum, $100 \mu \mathrm{g} / \mathrm{ml}$ gentamicin and $25 \mathrm{mmol} / \mathrm{L} \mathrm{KCl}$, at $37^{\circ} \mathrm{C}$ in a humidified $95 \%$ air, $5 \% \mathrm{CO}_{2}$ atmosphere. Cultures were treated with $10 \mu \mathrm{mol} / \mathrm{L}$ cytosine arabinoside from day 1 in order to minimize proliferation of non-neuronal cells. Primary cultures of rat type I astrocytes were established as previously reported [20]. Briefly, two-day-old Wistar rats were sacrificed by decapitation; brain cortices were rapidly removed and separated from meninges. Brains were minced and incubated in PBS containing trypsin $\left(0.125 \%\right.$ at $37^{\circ} \mathrm{C}$. for $\left.15 \mathrm{~min}\right)$. Digestion was stopped adding PBS containing $1 \%$ bovine serum albumine and was 
followed by mechanical trituration. The obtained cell dispersion was plated into $75 \mathrm{~cm}^{2}$ flask and cultured in DMEM supplemented with $10 \%$ fetal bovin serum, penicillin/streptomycin $(10 \mathrm{mmol} / \mathrm{L}), \mathrm{L}$-glutamine $(2 \mathrm{mmol} / \mathrm{L})$ and maintained in $5 \% \mathrm{CO}_{2}$ atmosphere at $37^{\circ} \mathrm{C}$. At confluence, flasks were shaken in rotation plates to remove microglia and type II astrocytes. Adherent cells were then divided (3:1 ratio) to grow a P1 generation. From confluent, P1 flasks was obtained a P2 generation of astrocytes that was used for most experiments. In some cases, a third (P3) generation was obtained, and enzyme expression was compared in the 3 (P1, P2 and P3) astrocyte generations. All animal experiments were carried out with authorization by the Italian ministry of Health and in compliance with the animal care requirements that are requested by Italian law (law D.L. 27.1.1992 n. 116, in agreement with the European Union directive 86/609/CEE).

\section{Cell treatment}

For $\mathrm{Cr}$ uptake experiments, rat cerebellar granule cells and astrocytes were incubated for 24 hours in a culture medium containing $1 \mathrm{mmol} / \mathrm{L} \mathrm{D3Cr}$ and with $1 \mathrm{mmol} / \mathrm{L} \mathrm{D} 3 \mathrm{Cr}$ plus $1 \mathrm{mmol} / \mathrm{L}$ GPA. D3Cr concentration was in accord with previously reported $\mathrm{Cr}$ incubation experiments [21].

For $\mathrm{Cr}$ and GAA synthesis experiments, astrocytes were incubated for 24 hours with $\left[{ }^{15} \mathrm{~N}_{2}\right] \mathrm{Arg}$ and $\left[{ }^{13} \mathrm{C}_{2},{ }^{15} \mathrm{~N}\right]$ Gly at three different concentrations $(5 \mathrm{mmol} / \mathrm{L}, 10 \mathrm{mmol} / \mathrm{L}$, and $15 \mathrm{mmol} / \mathrm{L}$ ). By contrast neuronal cerebellar granule cells were incubated with $\left[{ }^{15} \mathrm{~N}_{2}\right]$ Arg and $\left[{ }^{13} \mathrm{C}_{2},{ }^{15} \mathrm{~N}\right]$ Gly at the single concentration of $10 \mathrm{mmol} / \mathrm{L}$. This was done in order to optimize the number of cells available for each experiment, given the fact that neurons proliferated much less than astrocytes. Labelled precursor concentrations were in accord with incubation experiments previously reported in lymphoblasts [12]. For each experiment a sample of cells incubated in medium without labelled precursors (control sample) was included.

After 24 hours of incubation the medium was aspirated, cells were washed twice with $10 \mathrm{ml}$ of saline solution and detached from the flask's wall with trypsin. Afterwards, the cells were rapidly washed twice with $10 \mathrm{ml}$ of saline solution by suspension and centrifugation at $1200 \mathrm{~g}$ for $10 \mathrm{~min}$, to remove any contamination of labelled amino acids; pellets were then suspended into $100 \mu \mathrm{l}$ of saline solution and stored frozen at $-80^{\circ} \mathrm{C}$ until analysis. To lysate the cells, the pellets were frozen and thawed for six times at $-70^{\circ} \mathrm{C}$, placed in the ultrasonic bath for $30^{\prime}$ and then centrifuged at $15000 \mathrm{~g}$ for 30'. The supernatant was recovered, an aliquot was used for protein assay (Bio-rad, Hercules, CA, USA) and the remaining was deproteinized using the Centricon filters at $5000 \mathrm{~g}$ for 50'. The cell extract was then analysed by ESI-MS/MS. The incubation experiments were replicated 3 times and the cell extracts were analysed twice.

\section{MS/MS analysis}

ESI-MS/MS was used for the analysis of the cell extracts. In GAA and $\mathrm{Cr}$ synthesis experiments Gly, $\left[{ }^{13} \mathrm{C}_{2},{ }^{15} \mathrm{~N}\right] \mathrm{Gly}$, Arg, $\left[{ }^{15} \mathrm{~N}_{2}\right.$ ]Arg, GAA, [1,2- ${ }^{13} \mathrm{C}_{2},{ }^{15} \mathrm{~N}_{3}$ ]GAA, Cr and [1,2$\left.{ }^{13} \mathrm{C}_{2},{ }^{15} \mathrm{~N}_{3}\right] \mathrm{Cr}$ in the cell extract were simultaneously determined. For the study of CT1 expression $\mathrm{Cr}, \mathrm{D} 3 \mathrm{Cr}$ and GAA in the cell extracts were determined.

The cell extracts were diluted 1:5 with methanol/water $(80 / 20 \mathrm{v} / \mathrm{v})$ containing the internal standard $\left[1,2-{ }^{13} \mathrm{C}_{2}\right]$ GAA in order to obtain a final concentration of $0.5 \mu \mathrm{mol} / \mathrm{L}$. Then the sample was dried under a nitrogen flow at $45^{\circ} \mathrm{C}$ using an EvapArray Sample Concentator (Porvair Advanced Materials, UK) and derivatized to butyl esters using $3 \mathrm{~mol} / \mathrm{L} \mathrm{HCl}$ in $\mathrm{n}$-butanol solution at $60^{\circ} \mathrm{C}$ for $30 \mathrm{~min}$. After derivatization the sample was dried under a nitrogen flow at $45^{\circ} \mathrm{C}$ and then recovered with $100 \mu \mathrm{l}$ of methanol/water solution (80:20) containing $0.1 \%$ formic acid. Twenty microliters of the obtained sample was injected for the ESI-MS/MS analysis.

An Agilent 1100 micropump (Agilent Technologies, Wilmington, DE, USA) and a Series 200 autosampler (Perkin Elmer, USA) were used for solvent delivery and automated sample introduction. Mobile phase was methanol/water (80:20) at a flow rate of $40 \mu \mathrm{l} / \mathrm{min}$.

A triple quadruple mass spectrometer API 2000 (ABI Sciex, Toronto, Canada) equipped with a TurboIonSpray source was used. The data were acquired and processed using Analyst 1.1. Resolution and calibration adjustments of quadrupoles were made by direct infusion at a $10 \mu \mathrm{l} /$ min of a $0.1 \mathrm{mmol} / \mathrm{L}$ polypropyleneglycole solution by an infusion pump. Q1 and Q3 were used at unit and high resolution respectively. Turbo ion spray source was operated in the positive ion mode at $350^{\circ} \mathrm{C}$ with a drying-gas at 20 psi and a capillary voltage of $5500 \mathrm{~V}$. Nitrogen was used as curtain and collision gas. Multiple reaction monitoring was used for the detection of $[\mathrm{M}+\mathrm{H}]^{+}$and product ions. The declustering potentials were $23,27,19$ and $20 \mathrm{~V}$, collision exit potential were $2.8,2.0,0.4$, and $10 \mathrm{~V}$ and collision energy were 19, 26, 45 and $12 \mathrm{eV}$ for GAA, Cr, Arg, Gly respectively and the same parameters were used for their isotopomers.

As result of the GAA and Cr synthesis experimental conditions, labelled and unlabelled precursors coexisted inside the cells and therefore we obtained enzyme products with a different number of stable isotopes (monolabelled, trilabelled and pentalabelled products). Since the higher concentration of the labelled in respect to unlabelled precursors, the pentalabelled forms ([1,2- ${ }^{13}$ $\left.\mathrm{C}_{2},{ }^{15} \mathrm{~N}_{3}\right]$ GAA and $\left[1,2-{ }^{13} \mathrm{C}_{2},{ }^{15} \mathrm{~N}_{3}\right] \mathrm{Cr}$ ) were prevalent. Therefore we selected them as reference compounds, also considering that their signals were far from isotopic distribution of the natural compounds.

The ion transitions for the labelled products $\left[1,2-{ }^{13}\right.$ $\left.\mathrm{C}_{2},{ }^{15} \mathrm{~N}_{3}\right]$ GAA and $\left[1,2-{ }^{13} \mathrm{C}_{2},{ }^{15} \mathrm{~N}_{3}\right] \mathrm{Cr}$ were defined upon 
the study of fragmentation of corresponding unlabelled compounds. The fragmentation of the protonated molecular ion of GAA, producing the fragment ion at 101.1 $\mathrm{m} / \mathrm{z}$, involves the loss of a molecule of butene and ammonia, while the formation of $90.1 \mathrm{~m} / \mathrm{z}$ by protonated $\mathrm{Cr}$, involves the loss of a molecule of butene and cyanamide (Figure 1). According to this considerations we used 105.0 and $93.1 \mathrm{~m} / \mathrm{z}$ product ions for the quantification of respectively $\left[1,2-{ }^{13} \mathrm{C}_{2},{ }^{15} \mathrm{~N}_{3}\right]$ GAA and $\left[1,2-{ }^{13}\right.$ $\left.\mathrm{C}_{2},{ }^{15} \mathrm{~N}_{3}\right] \mathrm{Cr}$.

The ion transitions were reported in Table 1. The quantitative determination of Gly, $\left[{ }^{13} \mathrm{C}_{2},{ }^{15} \mathrm{~N}\right] \mathrm{Gly}$, Arg, $\left[{ }^{15} \mathrm{~N}_{2}\right.$ ] Arg, Cr, [1,2- $\left.{ }^{13} \mathrm{C}_{2},{ }^{15} \mathrm{~N}_{3}\right] \mathrm{Cr}$ and D3Cr were obtained using internal standard calibrations. For the construction of calibration curves four different concentrations of $\left[{ }^{13} \mathrm{C}_{2},{ }^{15} \mathrm{~N}\right]$ Gly, $\left[{ }^{15} \mathrm{~N}_{2}\right.$ ] Arg and D3Cr were used and the linear correlation coefficient was in all cases higher than 0.999. The isotope dilution method for the quantitation of labelled and unlabelled GAA was used.

Linearity, recovery, within-run precision (data not shown), and sensitivity (the LOD and LOQ, Table 1) were studied demonstrating that this method was sensitive, accurate and precise.

\section{Real time PCR}

RNA from different Rattus norvegicus (Sprague Dawley) tissues was obtained. RNA was isolated from Kidney, Liver, and astrocytes using RNeasy Mini Kit (QIAGEN, Milan, Italy), from cerebellar granule cells, using RNeasy Lipid Tissue Mini kit (QIAGEN, Milan, Italy) and from blood using QIAamp RNA Blood Minikit (QIAGEN, Milan, Italy) as described from manufacturer. cDNA synthesis from total RNA was performed with High Capacity cDNA Archive Kit (Applera Italia, Monza, Italy). The resulting cDNA template, at a concentration of $50 \mathrm{ng} / \mu \mathrm{l}$, was subjected to relative-quantitative Realtime PCR using Taqman gene expression assays (Applera Italia, Monza, Italy), the TaqMan Universal PCR Master
Table 1 Parent and product ion transitions used for analysis by mass spectrometry

\begin{tabular}{lllll}
\hline & $\begin{array}{l}\text { Parent ion } \\
\mathbf{m} / \mathbf{z}\end{array}$ & $\begin{array}{l}\text { Product ion } \\
\mathbf{m} / \mathbf{z}\end{array}$ & $\begin{array}{l}\text { LOD } \\
\text { (nmol/L) }\end{array}$ & $\begin{array}{l}\text { LOQ } \\
\text { (nmol/L) }\end{array}$ \\
\hline Gly & 132.1 & 76.1 & - & - \\
{$\left[{ }^{13} \mathrm{C}_{2}{ }^{15} \mathrm{~N}\right] \mathrm{Gly}$} & 135.1 & 78.6 & 8 & 30 \\
$\mathrm{Arg}$ & 231.2 & 70.2 & - & - \\
{$\left[{ }^{15} \mathrm{~N}_{2}\right]$ Arg } & 233.2 & 70.2 & 24 & 26 \\
$\mathrm{GAA}$ & 174.1 & 101.1 & - & - \\
{$\left[1,2-{ }^{13} \mathrm{C}_{2}{ }^{15} \mathrm{~N}_{3}\right] \mathrm{GAA}$,} & 179.1 & 105.0 & 30 & 50 \\
$\mathrm{Cr}^{\left.132-{ }^{13} \mathrm{C}_{2}{ }^{15} \mathrm{~N}_{3}\right] \mathrm{Cr}}$ & 188.1 & 90.1 & - & - \\
$\mathrm{D} 3 \mathrm{Cr}$ & 193.1 & 93.1 & 5 & 8 \\
{$\left[1,2-{ }^{13} \mathrm{C}_{2}\right] \mathrm{GAA}$ (IS) } & 176.1 & 103.1 & - & 3 \\
\hline
\end{tabular}

Parent and product ion transitions used in MRM and lower detection and quantitation limits are reported. The LOD and LOQ were estimated analyzing ten blank samples and were calculated adding to the mean concentration respectively 3 and 10 SD.

Mix (Applera Italia, Monza, Italy) and the Two-Step Real-Time PCR System (Applera Italia, Monza, Italy). Quantitative Real Time PCR analysis of AGAT, GAMT and SLC6A8 mRNA expression were carried out in a Two-Step Real-Time PCR System using the TaqMan Rat Gene Expression Assays Rn00562952_m1 for target gene GAMT (EC 2.1.1.2), Rn00578954_m1 for target gene AGAT (EC 2.1.4.1), Rn00506029_m1 for target gene SLC6A8 (Solute carrier family 6 member 8) and Rn99999916_s1 for the internal normalization gene GAPDH (Applera Italia, Monza Italy). For quantitative Real Time PCR analysis, each sample was run in triplicates and the entire analysis was confirmed at list twice. Each run included a no template control (NTC) to test for contamination of assay reagents. After an initial Amperase UNG Activation at $50^{\circ} \mathrm{C}$ for $2 \mathrm{~min}$, and a $95^{\circ} \mathrm{C}$ denaturation for $10 \mathrm{~min}$, the reactions were cycled 40 times with a $95^{\circ} \mathrm{C}$ denaturation for $15 \mathrm{~s}$, and a $60^{\circ} \mathrm{C}$ annealing for $1 \mathrm{~min}$. Three types of controls aimed at detecting genomic DNA contamination in the RNA sample or during the Reverse Transcription (RT) or

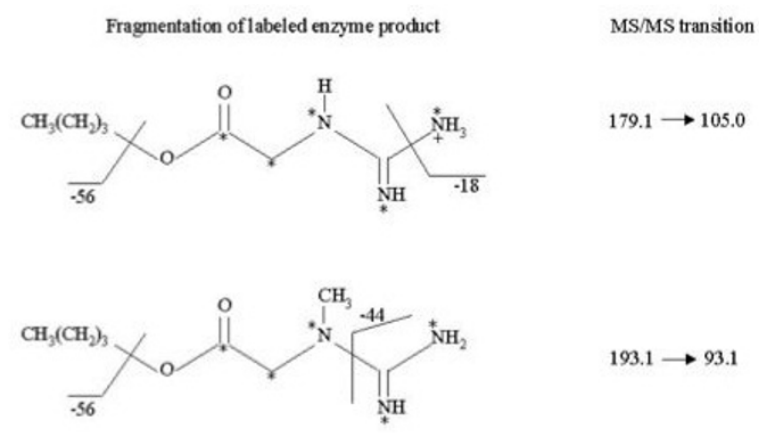

Figure 1 Analysis by MS/MS: fragmentation by collision-induced dissociation (CID). Fragmentation pattern and selected ion transitions ( $\mathrm{m} /$ z) of butylated $\left[1,2{ }^{13} \mathrm{C}_{2},{ }^{15} \mathrm{~N}_{3}\right] \mathrm{GAA}$ and $\left[1,2{ }^{-13} \mathrm{C}_{2},{ }^{15} \mathrm{~N}_{3}\right] \mathrm{Cr}$ used for MS/MS analyses are shown. 
quantitative Real Time PCR reactions were always included: a RT mixture without reverse transcriptase, a RT mixture including the enzyme but no RNA, negative control (reaction mixture without cDNA template). Relative quantification was performed using the comparative threshold (CT) method after determining the $\mathrm{CT}$ values for reference (GAPDH) and target (AGAT, GAMT and SLC6A8) genes in each sample sets according to the 2 $\triangle \triangle C T$ method. Changes in mRNA expression level were calculated after normalization to GAPDH. As calibrator sample we used cDNA from arbitrarily selected control cell line or tissue.

\section{Statistical analysis}

Unless otherwise indicated, all data are presented as the mean \pm SD. Student's $t$-test was used to determine the significance of differences between two group means. The relationship between two variables was tested using linear regression analysis. For statistical evaluation Statistica (StatSoft, Tulsa, USA) was used.

\section{Results}

\section{Cr uptake}

To investigate the functional expression of CT1 in cerebellar granule cells and astrocytes these cells were incubated with $\mathrm{D} 3 \mathrm{Cr}$, and its uptake was assessed in the presence or absence of GPA. After 24 hours of incubation with $1 \mathrm{mmol} / \mathrm{L}$ D3Cr, both cerebellar granule cells and astrocytes showed a high intracellular accumulation of the labelled compound $(24.4 \pm 5.3$ and $207.5 \pm 119.6 \mathrm{nmol} /$ $\mathrm{mg}$ protein, respectively). These values were as an average 10 and 122 times higher, respectively, than those of the endogenous (unlabelled) $\mathrm{Cr}$, that were $2.5 \pm 0.9$ and $1.7 \pm$ $0.6 \mathrm{nmol} / \mathrm{mg}$ protein, respectively in rat cerebellar granule cells and astrocytes. The addition of GPA to the culture medium resulted in $77 \pm 5 \%$ and $68 \pm 1 \%$ inhibition of the D3Cr uptake in cerebellar granule cells and astrocytes, respectively (Figure 2) and the difference in D3Cr accumulation in the presence and absence of GPA was significantly different (paired $t$-test, $\mathrm{N}=6, \mathrm{p}=0.006$ and $\mathrm{p}=$ 0.039 for granule cells and astrocytes, respectively), thus demonstrating that the uptake was largely dependent on the integrity of the $\mathrm{Cr}$ transporter.

\section{Cr synthesis in rat cerebellar granule cells}

Intracellular precursor accumulation, as well as GAA and $\mathrm{Cr}$ synthesis were investigated by comparing granule cells incubated with and without $\left[{ }^{13} \mathrm{C}_{2},{ }^{15} \mathrm{~N}\right]$ Gly and ${ }^{15} \mathrm{~N}_{2}$ Arg, $(10 \mathrm{mM})$. Results are summarized in Table 2. After 24 hours of incubation: a) the concentration of ${ }^{15} \mathrm{~N}_{2}$ - Arg was $56.3 \pm 20.4 \mathrm{nmol} / \mathrm{mg}$ protein and was similar to that of the endogenous, unlabelled Arg $(55.3 \pm 6.5 \mathrm{nmol} / \mathrm{mg}$ protein); b) $\left[{ }^{13} \mathrm{C}_{2},{ }^{15} \mathrm{~N}\right]$ Gly concentration was $710.5 \pm$ $216.1 \mathrm{nmol} / \mathrm{mg}$ protein and was higher than unlabelled
Gly (137.9 $\pm 29.8 \mathrm{nmol} / \mathrm{mg}$ protein); c) $\left[{ }^{13} \mathrm{C}_{2}{ }^{15} \mathrm{~N}_{3}\right]$ GAA concentration was $7.4 \pm 3.2 \mathrm{nmol} / \mathrm{mg}$ protein, which was 34 times the concentration of unlabelled GAA $(0.22 \pm$ $0.05 \mathrm{nmol} / \mathrm{mg}$ protein). $\left[{ }^{13} \mathrm{C}_{2}{ }^{15} \mathrm{~N}_{3}\right.$ ] GAA signal was 62 times the corresponding signal due to the background noise in control cells; d) $\left.{ }^{13} \mathrm{C}_{2}{ }^{15} \mathrm{~N}_{3}\right] \mathrm{Cr}$ concentration was $1.6 \pm 0.4 \mathrm{nmol} / \mathrm{mg}$ protein, $2.6 \%$ of the concentration of unlabelled endogenous $\mathrm{Cr}(62.2 \pm 15.3 \mathrm{nmol} / \mathrm{mg}$ protein $)$. $\left[{ }^{13} \mathrm{C}_{2}{ }^{15} \mathrm{~N}_{3}\right] \mathrm{Cr}$ signal was 40 times the corresponding signal due to the background noise in control samples.

\section{Cr synthesis in rat astrocytes}

Astrocytes were incubated for 24 hours with 3 different concentrations of $\left[{ }^{15} \mathrm{~N}_{2}\right]$ Arg and $\left[{ }^{13} \mathrm{C}_{2},{ }^{15} \mathrm{~N}\right]$ Gly $(5,10$ and $15 \mathrm{mmol} / \mathrm{L}$ ). Results are summarized in Table 3.

The intracellular levels of the labelled amino acids paralleled those in the medium and, except for the concentration of $5 \mathrm{mmol} / \mathrm{L}$, were higher than the concentrations of unlabelled Arg and Gly, thus demonstrating their uptake by astrocytes.

After incubation with labelled precursors, the $\left[{ }^{13} \mathrm{C}_{2},{ }^{15} \mathrm{~N}_{3}\right]$ GAA signal in cell extract was strongly increased, reaching 86 times the corresponding background noise in control samples. $\left[{ }^{13} \mathrm{C}_{2},{ }^{15} \mathrm{~N}_{3}\right]$ GAA concentration increased proportionally with the concentration of labelled precursors in the medium $\left(R^{2}>0.9229 ; p<0.002\right.$; Figure 3a). The ratio between $\left[{ }^{13} \mathrm{C}_{2}{ }^{15} \mathrm{~N}_{3}\right]$ GAA and the unlabelled, endogenous, GAA reached 18 (mean value) for the highest precursor concentration.

We found also a relevant increase of $\left[{ }^{13} \mathrm{C}_{2}{ }^{15} \mathrm{~N}_{3}\right] \mathrm{Cr}$, whose signal was significantly higher (up to 121 times higher) than the corresponding signal in control samples. No correlation was found between the $\left[{ }^{13} \mathrm{C}_{2}{ }^{15} \mathrm{~N}_{3}\right] \mathrm{Cr}$ levels and those of labelled precursors in the medium (Figure 3b) nor with intracellular $\left[{ }^{13} \mathrm{C}_{2}{ }^{15} \mathrm{~N}_{3}\right]$ GAA. The concentration of $\left[{ }^{13} \mathrm{C}_{2}{ }^{15} \mathrm{~N}_{3}\right] \mathrm{Cr}$ did not exceed $21 \%$ (mean value) of that of unlabelled endogenous $\mathrm{Cr}$.

\section{Gene expression}

To get information about the level of gene expression in rat astrocytes and cerebellar granule cells we used a PCRReal Time relative quantification. To this aim, we compared AGAT, GAMT and SLC6A8 gene expression in different tissues such as blood, kidney and liver. Figure 3 shows that AGAT and SLC6A8 transcripts were highly expressed in the kidney and GAMT in the liver, while a very low SLC6A8 expression was found in blood cells. Leukocytes expression was used as "calibrator" for the relative assessment of each gene, i.e. the amount of gene expression in blood cells was used as unit for the quantification of the expression in the other tissues. Among the tissues analyzed, after excluding the kidney in which it was very high (Figure 4, right panel), AGAT gene expression was higher in blood cells than in the liver (about 4/1). 

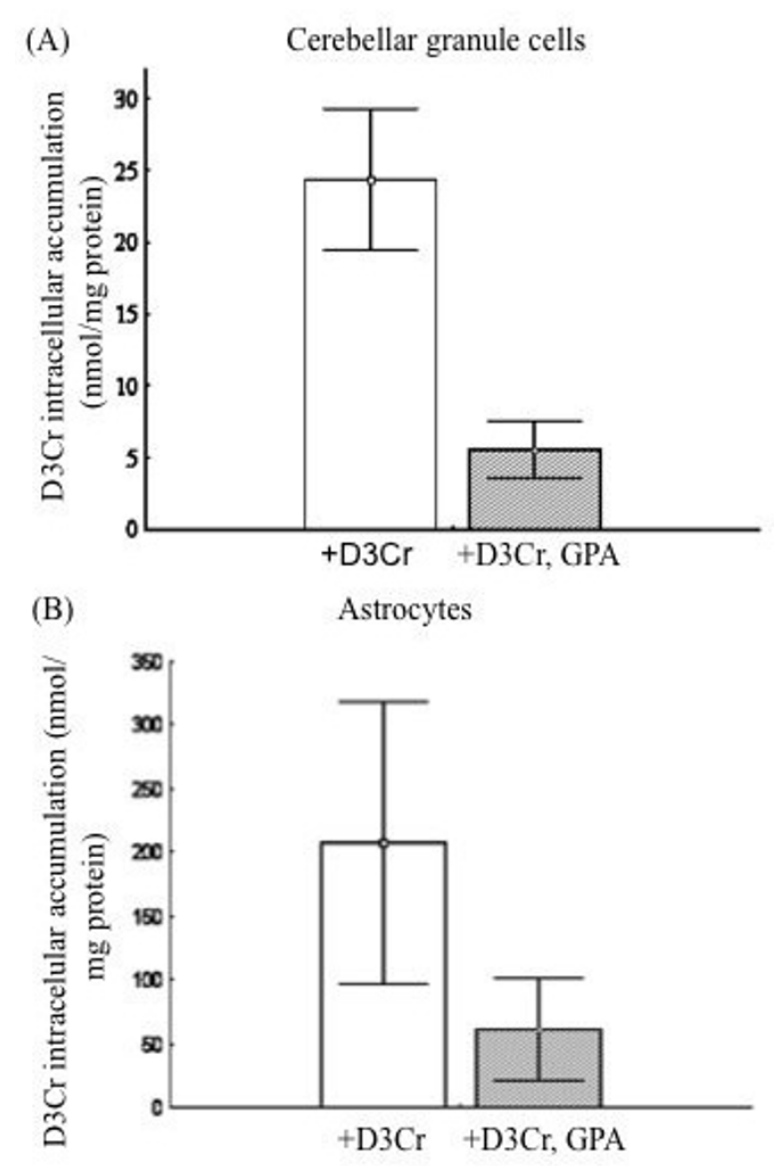

Figure 2 Functional expression of CT1 in rat cerebellar granule cells and astrocytes. Incubation of rat cerebellar granule cells (A) and astrocytes (B) with $1 \mathrm{mmol} / \mathrm{L} \mathrm{D3Cr}$ in culture medium in presence and absence of $1 \mathrm{mmol} / \mathrm{L}$ GPA: intracellular D3Cr mean values are given along with standard deviation for three different experiments (each sample was analysed two times). The addition in culture medium of GPA resulted in a marked inhibition of D3Cr uptake (77\% and 68\% respectively in cerebellar granule cells and astrocytes). D3Cr uptake in absence of GPA was significantly higher than that in presence of GPA, showing the occurrence of $\mathrm{Cr}$ active transport, in cerebellar granule cells as well as in astrocytes (paired Student's t-test, $N=6, p<0.05$ ). Difference in $\mathrm{D} 3 \mathrm{Cr}$ uptake between the two cell types was not statistically significant

(unpaired Student's $t$-test, $N=6, p=0.17$ ).

AGAT was about $1 / 3$ lower in astrocytes than in cerebellar granule cells $(\mathrm{p}<0.005)$ which, in turn, expressed $37 \%$ of blood cells.

GAMT gene was equally expressed in cerebellar granule cells and astrocytes (31 and 33\% of blood cell expression, respectively). We found that GAMT expression in the kidney was 3.5 times higher than in blood cells. SLC6A8 was about 3 times more expressed in cerebellar granule cells than in astrocytes $(\mathrm{p}<0.005)$. In order to test the possible influence of experimental conditions on gene expression, SLC6A8 transcripts were evaluated in P1, P2 and P3 generations of astrocytes by real time PCR. A stable and overlapping expression was found along the three cell generations (relative quantification expressed as $\log _{10}$ values were $2.06 \pm 1.61,2.09 \pm$ 1.66 and $2.09 \pm 1.68$ respectively for P1, P2 and P3 generations).

\section{Discussion}

Cellular incorporation of stable isotope from nutrient into downstream metabolites is largely used for the assessment of metabolic fluxes and the step of quantifying labelled and unlabelled molecules can be achieved by mass spectrometry, with the advantages of excellent sensitivity and linear dynamic range, and simultaneous detection of precursors, products, and associated isotopomers [22]. Labelled Arg and Gly have been successfully used to assess AGAT activity in lymphocytes and lymphoblasts [23] by gas-chromatography-mass spectrometry. Using this approach we have developed a new ESI-MS/MS method and investigated Cr uptake and synthesis in rat cerebellar granule cells and astrocytes by incubating the cells with either labelled $\mathrm{Cr}$ or with labelled Arg and Gly, which are the precursors of GAA and $\mathrm{Cr}$. 
Table 2 GAA and Cr synthesis experiments in rat cerebellar granule cells

\begin{tabular}{|c|c|c|c|}
\hline $\begin{array}{l}\text { Concentration of }\left[{ }^{15} \mathrm{~N}_{2}\right] \mathrm{Arg} \text { and }\left[{ }^{13} \mathrm{C}_{2},{ }^{15} \mathrm{~N}\right] \mathrm{Gly} \text { in the medium } \\
\text { (mmo1/L) }\end{array}$ & $\begin{array}{l}{\left[{ }^{15} \mathrm{~N}_{2}\right] \mathrm{Arg} \text { in the cells }} \\
\text { (nmol/mg protein) }\end{array}$ & $\begin{array}{l}\text { Arg in the cells } \\
\text { (nmol/mg } \\
\text { protein) }\end{array}$ & {$\left[{ }^{15} \mathrm{~N}_{2}\right] \mathrm{Arg} / \mathrm{Arg}$} \\
\hline 0 & $1.6 \pm 0.8$ & $153.4 \pm 105.3$ & $0.009 \pm 0.001$ \\
\hline \multirow[t]{2}{*}{10} & $56.3 \pm 20.4^{\mathrm{NS}}$ & $55.3 \pm 6.5$ & $1.00 \pm 0.25$ \\
\hline & $\begin{array}{l}{\left[{ }^{13} \mathrm{C}_{2}{ }^{15} \mathrm{~N}\right] \mathrm{Gly} \text { in the cells }} \\
\text { (nmol/mg protein) }\end{array}$ & $\begin{array}{l}\text { Gly in the cells } \\
\text { (nmol/mg } \\
\text { protein) }\end{array}$ & $\left.{ }^{13} \mathrm{C}_{2},{ }^{15} \mathrm{~N}\right]$ Gly/Gly \\
\hline 0 & $1.8 \pm 1.2$ & $470.8 \pm 232.7$ & $0.007 \pm 0.004$ \\
\hline \multirow[t]{2}{*}{10} & $710.5 \pm 216.1^{* *}$ & $137.9 \pm 29.8$ & $5.08 \pm 0.68$ \\
\hline & $\begin{array}{l}{\left[{ }^{13} \mathrm{C}_{2}^{15} \mathrm{~N}_{3}\right] \mathrm{GAA} \text { in the cells }(\mathrm{nmol} / \mathrm{mg}} \\
\text { protein) }\end{array}$ & $\begin{array}{l}\text { GAA in the cells } \\
\text { (nmol/mg } \\
\text { protein) }\end{array}$ & $\begin{array}{l}{\left[{ }^{13} \mathrm{C}_{2}^{15} \mathrm{~N}_{3}\right] \mathrm{GAA} /} \\
\mathrm{GAA}\end{array}$ \\
\hline 0 & $0.12 \pm 0.07$ & $2.08 \pm 1.43$ & $0.085 \pm 0.029$ \\
\hline \multirow[t]{2}{*}{10} & $7.4 \pm 3.2 *$ & $0.22 \pm 0.05$ & $33.3 \pm 7.9$ \\
\hline & $\begin{array}{l}{\left[{ }^{13} \mathrm{C}_{2}^{15} \mathrm{~N}_{3}\right] \mathrm{Cr} \text { in the cells }} \\
\text { (nmol/mg protein) }\end{array}$ & $\begin{array}{l}\mathrm{Cr} \text { in the cells } \\
\text { (nmol/mg } \\
\text { protein) }\end{array}$ & {$\left[{ }^{13} \mathrm{C}_{2}{ }^{15} \mathrm{~N}_{3}\right] \mathrm{Cr} / \mathrm{Cr}$} \\
\hline 0 & $0.04 \pm 0.02$ & $261.3 \pm 138.4$ & $<0.001$ \\
\hline 10 & $1.6 \pm 0.4^{* *}$ & $62.2 \pm 15.3$ & $0.027 \pm 0.007$ \\
\hline
\end{tabular}

Intracellular concentrations of Gly, $\left[{ }^{13} \mathrm{C}_{2},{ }^{15} \mathrm{~N}\right] \mathrm{Gly}$, $\operatorname{Arg},\left[{ }^{15} \mathrm{~N}_{2}\right] \mathrm{Arg}, \mathrm{GAA},\left[1,2-{ }^{13} \mathrm{C}_{2},{ }^{15} \mathrm{~N}_{3}\right] \mathrm{GAA}, \mathrm{Cr}$, and $\left[1,2-{ }^{13} \mathrm{C}_{2},{ }^{15} \mathrm{~N}_{3}\right] \mathrm{Cr}$ after 24 hours in vitro incubation with $10 \mathrm{mmol} /$ $\mathrm{L}\left[{ }^{15} \mathrm{~N}_{2}\right] \mathrm{Arg}$ and $10 \mathrm{mmol} / \mathrm{L}\left[{ }^{13} \mathrm{C}_{2}{ }^{15} \mathrm{~N}\right] \mathrm{Gly}$. Zero concentration in the first column (first line) corresponds to cells incubated in medium without labeled precursors. The value reported of labeled compounds is due to background noise. The statistical significance of the differences between intracellular concentrations of labeled and unlabeled compounds was assessed by paired Student's $t$-test: NS not significant, ${ }^{*} \mathrm{p}<0.05,{ }^{* *} \mathrm{p}<0.01$. The intracellular concentration of $\left[{ }^{13} \mathrm{C}_{2}{ }^{15} \mathrm{~N}\right]$ Gly was significantly higher than that of Gly and the concentration of $\left[{ }^{15} \mathrm{~N}_{2}\right] \mathrm{Arg}$ was similar to that of Arg. Accordingly, the intracellular $\left[{ }^{13} \mathrm{C}_{2}{ }^{15} \mathrm{~N}_{3}\right] \mathrm{GAA}$ concentration was significantly higher than GAA concentration whereas $\left[{ }^{13} \mathrm{C}_{2}^{15} \mathrm{~N}_{3}\right] \mathrm{Cr}$ is significantly lower than $\mathrm{Cr}$. The ratios express the relative intracellular availability of labeled and unlabeled forms (right column).

The converging results of our functional and gene expression studies showed that in the rat both neurons and astrocytes are capable to express the enzymatic machinery to both uptake and synthesize $\mathrm{Cr}$.

\section{Cr uptake}

Cr uptake in our study was greatly reduced by GPA, an inhibitor of CT1 [1,24], thus strongly suggesting that it mostly happens through this transporter. This functional result was supported by gene expression analysis, showing that both cell types express CT1. We confirmed previous data showing that adult rat cerebellar granule cells express the $\mathrm{Cr}$ transporter [15,25-27], that contributes in a relevant way to the whole intracellular pool of this compound. A low expression of $\mathrm{Cr}$ transporter in the rat brain soon after the birth and a rapid increase during the first weeks of life was reported by some studies [25], while others detected an earlier expression of $\mathrm{Cr}$ transporter in embryonic CNS [28]. By contrast, Moller and Hamprecht [29] found only a feeble Cr uptake in neuroblastoma cell line and no $\mathrm{Cr}$ transport in neuron-rich primary cultures from embryonic rat. Thus, our finding adds to the existing store of partially conflicting results.

Concerning $\mathrm{Cr}$ uptake by the astrocytes, our results confirm those of a previous study based on a kinetic approach [29]. On this topic, too, conflicting results are reported in the literature. CT1 was detected in perivascular astrocytes of the retina [30] and cerebellum [31], but not in other regions of CNS [31], while no CT1 expression was found in astrocytes by in situ hybridization $[15,27]$. Braissant et al. [21] showed that protracted exposure to very high levels of $\mathrm{NH} 4 \mathrm{Cl}$ induced SLC6A8 transcription and translation in astrocytes, where it became then detectable by in situ hybridization and immunohistochemistry, thus suggesting that the SLC6A8 gene may be differentially expressed under different experimental conditions. To the best of our knowledge, $\mathrm{NH} 4 \mathrm{Cl}$ is the only factor that has been proven to induce expression of the SLC6A8 gene [21]. However, the reliability of our results is supported by the stability of SLC6A8 transcription in three generations of cultured astrocytes (P1, P2 and P3), suggesting that SLC6A8 expression is not affected by the in vitro condition.

As a word of caution, while our findings show that astrocytes have the capability to express the Cr transporter, and to uptake $\mathrm{Cr}$, we can not rule out that this capability may be differently expressed in different conditions.

\section{Cr synthesis}

Our findings show that both granule cells and astrocytes are capable to uptake Arg and Gly and to use them to synthesize GAA and Cr. Again, these functional findings are supported by gene expression analysis, showing that 
Table 3 GAA and $\mathrm{Cr}$ synthesis experiments in rat astrocytes

\begin{tabular}{|c|c|c|c|}
\hline $\begin{array}{l}\text { Concentration of }\left[{ }^{15} \mathrm{~N}_{2}\right] \mathrm{Arg} \text { and }\left[{ }^{13} \mathrm{C}_{2},{ }^{15} \mathrm{~N}\right] \mathrm{Gly} \\
\text { in the medium }(\mathrm{mmol} / \mathrm{L})\end{array}$ & $\begin{array}{l}{\left[{ }^{15} \mathrm{~N}_{2}\right] \text { Arg in the cells }} \\
\text { (nmol/mg protein) }\end{array}$ & $\begin{array}{l}\text { Arg in the cells } \\
\text { (nmol/mg protein) }\end{array}$ & {$\left[{ }^{15} \mathrm{~N}_{2}\right] \mathrm{Arg} / \mathrm{Arg}$} \\
\hline 0 & $1.8 \pm 1.1$ & $172.0 \pm 78.2$ & $0.01 \pm 0.00$ \\
\hline 5 & $137.9 \pm 71.6^{\mathrm{NS}}$ & $145.5 \pm 73.4$ & $1.12 \pm 0.52$ \\
\hline 10 & $504.0 \pm 390.0 *$ & $178.6 \pm 137.9$ & $3.43 \pm 1.66$ \\
\hline \multirow[t]{2}{*}{15} & $957.4 \pm 500.45^{* *}$ & $215.5 \pm 132.5$ & $6.74 \pm 4.72$ \\
\hline & $\begin{array}{l}{\left[^{13} \mathrm{C}_{2}{ }^{15} \mathrm{~N}\right] \mathrm{Gly} \text { in the cells }} \\
\text { (nmol/mg protein) }\end{array}$ & $\begin{array}{l}\text { Gly in the cells } \\
\text { (nmol/mg protein) }\end{array}$ & {$\left[{ }^{13} \mathrm{C}_{2},{ }^{15} \mathrm{~N}\right] \mathrm{Gly} / \mathrm{Gly}$} \\
\hline 0 & $2.8 \pm 0.9$ & $365.7 \pm 43.2$ & $0.01 \pm 0.00$ \\
\hline 5 & $1003.8 \pm 1083.3^{N S}$ & $696.3 \pm 604.2$ & $1.28 \pm 0.49$ \\
\hline 10 & $2205.5 \pm 2382.0 *$ & $893.8 \pm 958.4$ & $2.53 \pm 0.22$ \\
\hline \multirow[t]{2}{*}{15} & $3213.9 \pm 2482.9 *$ & $744.8 \pm 512.7$ & $4.43 \pm 0.85$ \\
\hline & $\begin{array}{l}{\left[{ }^{13} \mathrm{C}_{2}^{15} \mathrm{~N}_{3}\right] \mathrm{GAA} \text { in the cells }} \\
\text { (nmol/mg protein) }\end{array}$ & $\begin{array}{l}\text { GAA in the cells } \\
\text { (nmol/mg protein) }\end{array}$ & {$\left[{ }^{13} \mathrm{C}_{2}{ }^{15} \mathrm{~N}_{3}\right] \mathrm{GAA} / \mathrm{GAA}$} \\
\hline 0 & $0.25 \pm 0.09$ & $1.46 \pm 1.46$ & $0.29 \pm 0.14$ \\
\hline 5 & $10.34 \pm 7.90 *$ & $2.37 \pm 2.23$ & $4.47 \pm 3.97$ \\
\hline 10 & $17.18 \pm 13.36 *$ & $1.88 \pm 1.87$ & $13.30 \pm 14.32$ \\
\hline \multirow[t]{2}{*}{15} & $21.59 \pm 15.00 * *$ & $1.64 \pm 1.11$ & $18.18 \pm 17.96$ \\
\hline & $\begin{array}{l}{\left[{ }^{13} \mathrm{C}_{2}^{15} \mathrm{~N}_{3}\right] \mathrm{Cr} \text { in the cells }} \\
\text { (nmol/mg protein) }\end{array}$ & $\begin{array}{l}\mathrm{Cr} \text { in the cells } \\
\text { ( } \mathrm{nmol} / \mathrm{mg} \text { protein) }\end{array}$ & {$\left[{ }^{13} \mathrm{C}_{2}{ }^{15} \mathrm{~N}_{3}\right] \mathrm{Cr} / \mathrm{Cr}$} \\
\hline 0 & $0.10 \pm 0.05$ & $100.4 \pm 118.7$ & $0.00 \pm 0.00$ \\
\hline 5 & $12.13 \pm 12.64 *$ & $86.53 \pm 71.65$ & $0.12 \pm 0.04$ \\
\hline 10 & $10.88 \pm 8.48^{* *}$ & $59.48 \pm 23.72$ & $0.17 \pm 0.08$ \\
\hline 15 & $11.00 \pm 6.85 * *$ & $48.54 \pm 10.58$ & $0.21 \pm 0.09$ \\
\hline
\end{tabular}

Intracellular concentrations of Gly, $\left[{ }^{13} \mathrm{C}_{2},{ }^{15} \mathrm{~N}\right] \mathrm{Gly}$, Arg, $\left[{ }^{15} \mathrm{~N}_{2}\right] \mathrm{Arg}, \mathrm{GAA},\left[1,2-{ }^{13} \mathrm{C}_{2},{ }^{15} \mathrm{~N}_{3}\right] \mathrm{GAA}, \mathrm{Cr}$ and $\left[1,2-{ }^{13} \mathrm{C}_{2}{ }^{15} \mathrm{~N}_{3}\right] \mathrm{Cr}_{\text {after }} 24 \mathrm{~h}$ in vitro incubation with $\left[{ }^{15} \mathrm{~N}_{2}\right] \mathrm{Arg}$ and $\left[{ }^{13} \mathrm{C}_{2},{ }^{15} \mathrm{~N}\right] \mathrm{Gly}$ under different concentrations of labeled precursors in the medium: no labeled precursors $(0), 5,10$ and $15 \mathrm{mmol} / \mathrm{L}$. The statistical significance of the differences between intracellular concentrations of labeled and unlabeled compounds was assessed by paired Student's $t$-test: NS not significant, ${ }^{*} \mathrm{p}<0.05$, ** $\mathrm{p}<0.01$. The concentrations of $\left[{ }^{13} \mathrm{C} 2,{ }^{15} \mathrm{~N}\right] \mathrm{Gly}$ and $\left[{ }^{15} \mathrm{~N}_{2}\right]$ Arg were significantly higher than those of Gly and Arg (except for cells incubated with $\left[{ }^{15} \mathrm{~N}_{2}\right]$ Arg $\mathrm{mmol} / \mathrm{L}$ ), showing that the labeled precursors are highly available into the cells for $\mathrm{Cr}$ synthesis. $\left[{ }^{13} \mathrm{C}_{2}{ }^{15} \mathrm{~N}_{3}\right] \mathrm{GAA}$ concentrations were also significantly higher than those of GAA, whereas $\left[{ }^{13} \mathrm{C}_{2},{ }^{15} \mathrm{~N}_{3}\right] \mathrm{Cr}$ levels remained significantly lower than those of $\mathrm{Cr}$. The ratios express the relative intracellular availability of labeled and unlabeled forms (right column).

both cell types express AGAT and GAMT, the enzymes that are required to synthesize $\mathrm{Cr}$ from Arg and Gly, which have their own transporters at the blood brain barrier and on the plasma membrane of nervous cells [32-35]. We found that labelled Gly was taken up by both astrocytes and neurons in a quantity larger than labelled Arg (Table 2 and 3). That probably depends on different characteristics of the corresponding transporters, whose investigation however was outside the scope of our paper. Previous studies demonstrated GAMT activity in neuroblastoma cell lines [16]. They also demonstrated $\mathrm{Cr}$ synthesis from Gly in astroglial cells (at a rate dependent on Arg and Methionine levels in the substrate [17]), and in brain cell 3D cultures (that are able to convert the GAA taken-up from medium into $\mathrm{Cr}$ [36]). Moreover, AGAT and (to a lesser extent) GAMT mRNA were ubiquitously found in the adult rat brain by in situ hybridization [15].

\section{Cr synthesis vs. Uptake}

An important difference arises in our data between $\mathrm{Cr}$ synthesis and uptake when we consider the magnitude of the results. Cr uptake was in our hands a very efficient process in both granule cells and astrocytes. After incubation with labelled $\mathrm{Cr}$ the $91 \%$ and $99 \%$ of the total intracellular $\mathrm{Cr}$ content, respectively in neurons and in astrocytes, is due to transport. This effect is very robust and sizable. By contrast, after 24 hours cell incubation with high concentrations of $\mathrm{Cr}$ precursors Arg and Gly, the de novo synthesized $\mathrm{Cr}$ was only about $2.7 \%$ (in the case of neurons) and 12-21\% (in the case of astrocytes). The remaining unlabelled $\mathrm{Cr}$ could be ascribed to pre-existing intracellular $\mathrm{Cr}$ pool, to calf serum in culture medium (see methods) and to de novo synthesis starting from unlabelled precursors. However the contribution of unlabelled precursors to $\mathrm{Cr}$ synthesis is relatively negligible since their intracellular concentrations were minor or equal to labelled ones. Furthermore, it should be noted that the intermediate labelled product GAA was highly available for $\mathrm{Cr}$ synthesis in both cell types, increasing 33 times in neurons and up to about 18 times in astrocytes (Tables 2 and 3). In astrocytes it was possible to study the relationship between precursors concentration and GAA or Cr content. A linear 


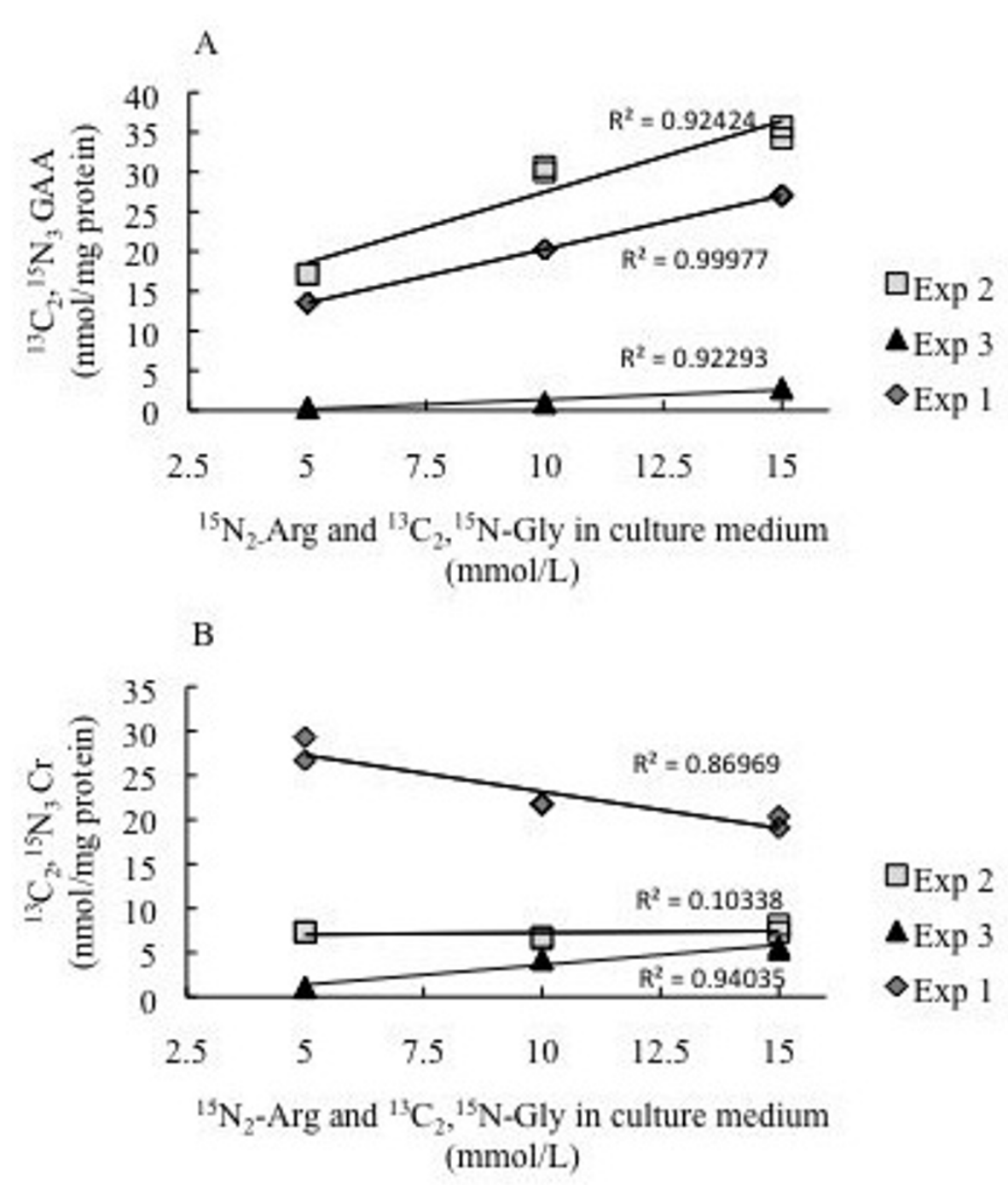

Figure 3 Functional expression of GAMT and AGAT in rat astrocytes. Intracellular $\left[{ }^{13} \mathrm{C}_{2},{ }^{15} \mathrm{~N}_{3}\right] \mathrm{GAA}(\mathrm{A})$ and $\left[{ }^{13} \mathrm{C}_{2},{ }^{15} \mathrm{~N}_{3}\right] \mathrm{Cr}$ (B) Concentrations in function of $\left[{ }^{13} \mathrm{C}_{2}\right.$, $\left.{ }^{15} \mathrm{~N}\right] \mathrm{Gly}$ and $\left[{ }^{15} \mathrm{~N}_{2}\right]$ Arg concentrations in culture medium, in three sets of cell samples (experiment 1,2 and 3) are reported. To test the correlation among the intracellular concentration of labelled products and the precursor concentrations in culture medium, linear regression analysis was performed. Whereas there was a linear correlation for labelled GAA ( $<$ 0.0022), no clear and consistent linear correlation for labelled $\mathrm{Cr}$ was found. Both graphs show that the cultures of experiment 3 yielded a lesser amount of GAA and Cr. Inspection of the cultures did not provide any obvious explanation for this result.

relationship was found for GAA, while no such relationship was found for Cr. Taken together, these results suggest that in brain cells both $\mathrm{Cr}$ synthesis and uptake are possible, and that under the in vitro conditions we used the latter is more efficient than the former. Moreover, they suggest that the most critical step in the synthesis of $\mathrm{Cr}$ by brain cells is the conversion of GAA into $\mathrm{Cr}$, both in neurons and in astrocytes. We do not exactly know why the conversion of GAA into $\mathrm{Cr}$ is so limited. Tachikawa et al. [18] demonstrated by an immunohistochemical approach a preferential glial expression of GAMT coupled with a preferential neuronal expression of ubiquitous mitochondrial CK in the adult mouse brain. This pattern of enzyme segregation suggested that neuronal $\mathrm{Cr}$ is supplied to nervous cells by local glial cells [18], a hypothesis later supported by some of us [37]. In this complex homeostatic model, which mimics the general separation between sites of $\mathrm{Cr}$ synthesis and utilization outside the CNS [1], the possible pivotal role of GAA remains to be clarified. Apart from endogenous synthesis, GAA is up taken by nervous cells via Cr [18] and Taurine [38] transporters and in brain parenchyma it is converted to $\mathrm{Cr}$ even if in a low proportion (29\%) [36].

This issue was further addressed by exploring the coexpression of AGAT, GAMT and SLC6A8 proteins in rat 

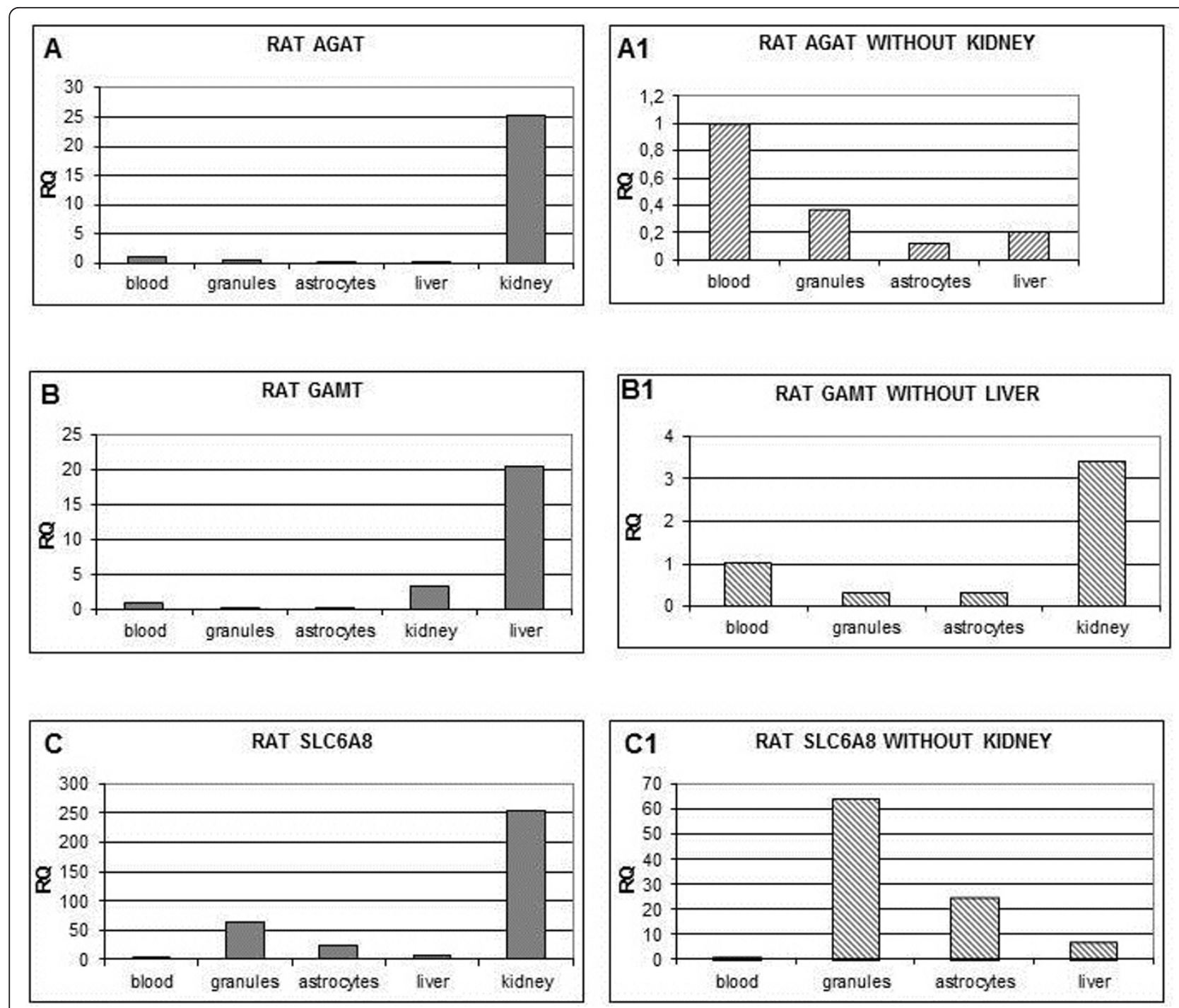

Figure 4 Relative quantification of gene expression using Real Time PCR. Blood expression level is used as calibrator (Relative quantification $(R Q)=1)$. Panels at right side $(A 1, B 1, C 1)$ are a magnification of those on the left side $(A, B, C)$ excluding tissues with higher expression level.

grey matter cells $[27,36]$. These studies suggested that GAA and $\mathrm{Cr}$ synthesis may occur in different cells, and that GAA needs to be transferred between cells to be converted into Cr. By providing functional evidence that the conversion of GAA into Cr by brain cells is a quantitatively limited process, our findings do provide some support to that hypothesis. Alternatively, we should not underestimate the possible limiting effect of the availability of other metabolites involved in Cr homeostasis, such as S-adenosylmetionine [29], even if the limiting effect of this metabolite on $\mathrm{Cr}$ synthesis is considered not relevant under normal condition [1].

\section{Clinical implications}

The presence of CT1 in both astrocytes and cerebellar granule cells, as well as in the endothelium of brain capillaries [39], and in choroid plexus during the embryonic development [28] strongly supports the view that blood $\mathrm{Cr}$ supply is an important source of brain $\mathrm{Cr}$ in physiological conditions. This conclusion is compatible with the metabolic pattern detected in patients affected by CT1 deficiency $[9,40]$ as well as with the restoration of brain $\mathrm{Cr}$ under $\mathrm{Cr}$ supplementation observed in the defects of Cr synthesis: in AGAT deficiency (differently from GAMT deficiency, where GAA accumulates and competes with $\mathrm{Cr}$ for the CT1 transporter) $40 \%$ and $80 \%$ restoration of normal brain $\mathrm{Cr}$ level was obtained after 3 and 9 months of treatment, respectively $[9,11]$. A dosage as low as $100 \mathrm{mg} / \mathrm{kg} / \mathrm{bw} /$ day was sufficient to replenish $60 \%$ of brain $\mathrm{Cr}$ and prevents the emergence of the disease in an early diagnosed and treated child with AGAT deficiency [9]. This support the view that $\mathrm{Cr}$ transport is 
probably much more efficient during fetal to perinatal and postnatal stages [28]. The increase of brain $\mathrm{Cr}$ observed in normal subjects under protracted $\mathrm{Cr}$ loading is much less relevant (3.5-13.3\%), notwithstanding the concomitant increase of blood Cr from 50 to $800 \mu \mathrm{mol} / \mathrm{L}$ [41]. Similar results, which have been confirmed in animal models [42-44], overall support the view that $\mathrm{Cr}$ pool in CNS is subjected to a homeostatic control.

The above results may offer an explanation of the conflicting results that were obtained in patients affected by CT1 deficiency when treated with the $\mathrm{Cr}$ precursors in order to stimulate the endogenous synthesis of $\mathrm{Cr}$. Our data suggest that $\mathrm{Cr}$ synthesis by brain cells may be limited, in such a way to possibly provide only a limited amount of the $\mathrm{Cr}$ that is needed by the brain.

Some limitations inherent to our study suggest caution in extrapolating our results to the in vivo conditions. In fact, we investigated only two kinds of cells from the cerebellum, while different brain regions and cells could be differently equipped in term of CK activity and related $\mathrm{Cr}$ availability [31]. Moreover, the need of large supplementation of $\mathrm{Cr}$ in patients with deficient $\mathrm{Cr}$ synthesis, and normal or increased CSF $\mathrm{Cr}$ - but not brain ${ }^{1} \mathrm{H}$-MRS $\mathrm{Cr}$ - in few CT1 deficient patients before [45] or during $\mathrm{Cr}$ treatment [5,13], remain to be explained. The recently developed $\mathrm{Cr}$ transporter knockout mice, that mimics several aspects of the human disease, will provide an exciting opportunity to verify different models of $\mathrm{Cr}$ transport and synthesis inside the CNS [46].

Summing up, while further research is needed to fully understand to what extent these in vitro results are relevant to the in vivo situation, our results show that both astrocytes and neurons possess the capability to both synthesize and uptake $\mathrm{Cr}$, but that the latter is probably more robust than the former.

\footnotetext{
Abbreviations

Arg: arginine; AGAT L-arginine:glycine amidinotransferase; Cr: creatine; [ ${ }^{13}$ $\left.\mathrm{C}_{2}{ }^{15} \mathrm{~N}\right] \mathrm{Gly}$ : ${ }^{13} \mathrm{C}_{2}{ }^{15} \mathrm{~N}$ ]glycine; CT1: creatine transporter; D3Cr: $\mathrm{D}_{3}$-creatine; GAA: guanidinoacetic acid; GAMT: S-adenosylmethionine:guanidinoacetate $\mathrm{N}$-methyltransferase; Gly: glycine; GPA: $\beta$-guanidinopropionate; $\left[{ }^{15} \mathrm{~N}_{2}\right]$ Arg: L[guanido- ${ }^{15} \mathrm{~N}_{2}$ ] arginine; SLC6A8: creatine transporter gene; CNS: central nervous system; ESI-MS/MS: electrospray ionization tandem mass spectrometry; $\left[1,2-{ }^{13} \mathrm{C}_{2}\right] \mathrm{GAA}:{ }^{13} \mathrm{C}_{2}$-guanidinoacetic acid; $\left[{ }^{13} \mathrm{C}_{2},{ }^{15} \mathrm{~N}_{3}\right] \mathrm{GAA}$ : [1,2${ }^{13} \mathrm{C}_{2},{ }^{15} \mathrm{~N}_{3}$ ] guanidinoacetic acid; $\left[{ }^{13} \mathrm{C}_{2},{ }^{15} \mathrm{~N}_{3}\right] \mathrm{Cr}$ : $\left[1,2-{ }^{13} \mathrm{C}_{2},{ }^{15} \mathrm{~N}_{3}\right]$ creatine.
}

\section{Author details}

'Department of Experimental Medicine, La Sapienza Università di Roma, Viale del Policlinico 155, Rome 00161, Italy. '2Department of Neuroscience, Ophthalmology and Genetics, University of Genova, Via De Toni, 5, Genoa 16132, Italy. ${ }^{3}$ Department of Oncology, Biology and Genetics, University of Genova, Largo Rosanna Benzi, 10, Genoa 16132, Italy. ${ }^{4}$ Department of Physics, University of Genova, Via Dodecaneso, 33, Genoa 16146, Italy. ${ }^{5}$ Dept of Child Neurology and Psychiatry, La Sapienza Università di Roma, Via dei Sabelli 108, Rome 00185, Italy. ${ }^{6}$ Department of Molecular Medicine, La Sapienza Università di Roma, Viale Regina Elena 324, Rome 00161, Italy.

\section{Authors' contributions}

All Authors have each made a substantial contribution so as to qualify for authorship.

Specifically: a) CC, SS, and IA set up the new MS/MS methods for the intracellular assessment of labelled and unlabelled metabolites. They also were involved in the development of the experimental design and cooperated in the interpretation of the metabolic results; b) CC and CA performed genetic and metabolic molecular studies, interpreted genetic results and cooperated in the discussion concerning the linkage between biochemical and molecular results; c) EA, ST, EG, MR, and TF developed the in vitro model; arranged and accomplished cell coltures with labelled $\mathrm{Cr}$ and Cr precursors; d) VL and MB conceived and developed the experimental design, addressed the discussion on the interpretation of the results and coordinated the collaborative study. All authors read and approved the final manuscript.

\section{Competing interests}

The authors declare that they have no competing interests.

Received: 12 August 2011 Accepted: 26 April 2012

Published: 26 April 2012

\section{References}

1. Wyss M, Kaddurah-Daouk R: Creatine and creatinine metabolism. Physio/ Rev 2000, 80:1107-1212.

2. Balestrino M, Lensman M, Parodi M, Perasso L, Rebaudo R, Melani R, Polenov S, Cupello A: Role of creatine and phosphocreatine in neuronal protection from anoxic and ischemic damage. Amino Acids 2002, 23:221-229.

3. Item CB, Stöckler-Ipsiroglu S, Stromberger C, Mühl A, Alessandrì MG, Bianchi MC, Fornai F, Cioni G: Arginine:glycine amidinotransferase deficiency: the third inborn error of creatine metabolism in humans. Am J Hum Genet 2001, 69:1127-1133.

4. Stöckler S, Holzbach U, Hanefeld F, Marquartdt I, Helms G, Requart M, Hänicke W, Frahm J: Creatine deficiency in the brain: a new, treatable inborn error of metabolism. Pediatr Res 1994, 36:409-413.

5. Cecil KM, Salomons GS, Ball WS, Wong B, Chuck G, Verhoeven NM, Jakobs C, DeGraw TJ: Irreversible brain creatine deficiency with elevated serum and urine creatine: a creatine transporter defect? Ann Neurol 2001, 49:401-404.

6. Salomons GS, van Dooren SJ, Verhoeven NM, Cecil KM, Ball WS, Degrauw TJ, Jakobs C: X-linked creatine-transporter gene (SLC6A8) defect: A new creatine-deficiency syndrome. Am J Hum Genet 2001, 68:1497-1500.

7. Bianchi MC, Tosetti M, Fornai F, Alessandri MG, Cipriani P, De Vito G, Canapicchi R: Reversible brain creatine deficiency in two sisters with normal blood creatine level. Ann Neurol 2000, 47:511-513.

8. Mercimek-Mahmutoglu S, Stoeckler-Ipsiroglu S, Adami A, Appleton R, Araújo HC, Duran M, Ensenauer R, Fernandez-Alvarez E, Garcia P, Grolik C, Item CB, Leuzzi V, Marquardt I, Mühl A, Saelke-Kellermann RA, Salomons GS, Schulze A, Surtees $R$, van der Knaap MS, Vasconcelos R, Verhoeven NM, Vilarinho L, Wilichowski E, Jakobs C: GAMT deficiency: features, treatment, and outcome in an inborn error of creatine synthesis. Neurology 2006, 67:480-494.

9. Battini R, Alessandrì MG, Leuzzi V, Moro F, Tosetti M, Bianchi MC, Cioni G: Arginine:glycine amidinotransferase (AGAT) deficiency in a newborn: early treatment can prevent phenotypic expression of the disease. $J$ Pediatr 2006, 148:828-830.

10. Schulze A, Hoffmann GF, Bachert P, Kirsch S, Salomons GS, Verhoeven NM, Mayatepek E: Presymptomatic treatment of neonatal guanidinoacetate methyltransferase deficiency. Neurology 2006, 67:719-721.

11. Bianchi MC, Tosetti M, Battini R, Leuzzi V, Alessandri MG, Carducci C, Antonozzi I, Cioni G: Treatment monitoring of brain creatine deficiency syndromes: a $1 \mathrm{H}$ - and 31P-MR spectroscopy study. Am J Neuroradiol 2007, 28:548-554.

12. Leuzzi V, Alessandrì MG, Casarano M, Battini R, Cioni G: Arginine and glycine stimulate creatine synthesis in creatine transporter 1-deficient lymphoblasts. Anal Biochem 2008, 375:153-155.

13. Chilosi A, Leuzzi V, Battini R, Tosetti M, Ferretti G, Comparini A, Casarano M, Moretti E, Alessandri MG, Bianchi MC, Cioni G: Treatment with L-arginine 
improves neuropsychological disorders in a child with creatine transporter defect. Neurocase 2008, 14:151-161.

14. Fons C, Sempere A, Arias A, López-Sala A, Póo P, Pineda M, Mas A, Vilaseca MA, Salomons GS, Ribes A, Artuch R, Campistol J: Arginine supplementation in four patients with X-linked creatine transporter defect. J Inherit Metab Dis 2008, 31:724-728.

15. Braissant O, Henry H, Loup M, Eilers B, Bachmann C: Endogenous synthesis and transport of creatine in the rat brain: an in situ hybridization study. Brain Res Mol Brain Res 2001, 86:193-201.

16. Daly MM: Guanidinoacetate methyltransferase activity in tissues and cultured cells. Arch Biochem Biophys 1985, 236:576-584.

17. Dringen R, Verleysdonk S, Hamprecht B, Willker W, Leibfritz D, Brand A: Metabolism of glycine in primary astroglial cells: synthesis of creatine, serine, and glutathione. J Neurochem 1998, 70:835-840.

18. Tachikawa M, Fujinawa J, Takahashi M, Kasai Y, Fukaya M, Sakai K, Yamazaki M, Tomi M, Watanabe M, Sakimura K, Terasaki T, Hosoya K: Expression and possible role of creatine transporter in the brain at the blood-cerebrospinal fluid barrier as transporting protein of guanidinoacetate, an endogenous convulsant. J Neurochem 2008, 107:768-778.

19. Robello M, Amico C, Cupello A: Regulation of GABA-A receptor in cerebellar granule cells inculture: Differential involvement of kinase activities. Neuroscience 1993, 53:131-138.

20. Thellung S, Villa V, Corsaro A, Pellistri F, Venezia V, Russo C, Aceto A, Robello M, Florio T: ERK1/2 and p38 MAP kinases control prion protein fragment 90-231-induced astrocyte proliferation and microglia activation. GLIA 2007, 55:1469-1485.

21. Braissant O, Cagnon L, Monnet-Tschudi F, Speer O, Wallimann T, Honegger $\mathrm{P}$, Henry $\mathrm{H}$ : Ammonium alters creatine transport and synthesis in a 3D culture of developing brain cells, resulting in secondary cerebral creatine deficiency. Eur J Neurosci 2008, 27:1673-1685.

22. Yuan J, Bennett BD, Rabinowitz JD: Kinetic flux profiling for quantitation of cellular metabolic fluxes. Nat Protoc 2008, 3:1328-1340.

23. Verhoeven NM, Schor DS, Roos B, Battini R, Stöckler-Ipsiroglu S, Salomons GS, Jakobs C: Diagnostic enzyme assay that uses stable isotope-labelled substrates to detect L-arginine:glycine amidinotransferase deficiency. Clin Chem 2003, 49:803-805

24. Balestrino M, Gandolfo C, Perasso L: Controlling the flow of energy: inhibition and stimulation of the creatine transporter. Curr Enzym Inhib 2009, 5:223-233

25. Saltarelli MD, Bauman AL, Moore KR, Bradley CC, Blakely RD: Expression of the rat brain creatine transporter in situ and in transfected HeLa cells. Dev Neurosci 1996, 18:524-534.

26. Hiel H, Happe HK, Warr WB, Morley BJ: Regional distribution of a creatine transporter in rat auditory brainstem: an in-situ hybridization study. Hear Res 1996, 98:29-37.

27. Braissant O, Henry H: AGAT, GAMT and SLC6A8 distribution in the central nervous system, in relation to creatine deficiency syndromes: A review. J Inherit Metab Dis 2008, 31:230-239.

28. Braissant O, Henry H, Villard AM, Speer O, Wallimann T, Bachmann C: Creatine synthesis and transport during rat embryogenesis: spatiotemporal expression of AGAT, GAMT and CT1. BMC Dev Biol 2005, 26:5-9.

29. Möller A, Hamprecht B: Creatine transport in cultured cells of rat and mouse brain. J Neurochem 1989, 52:544-550.

30. Acosta ML, Kalloniatis M, Christie DL: Creatine transporter localization in developing and adult retina: importance of creatine to retinal function. Am J Physiol Cell Physiol 2005, 289:1015-1023.

31. Mak CS, Waldvogel HJ, Dodd JR, Gilbert RT, Lowe MT, Birch NP, Faull RL, Mak Christie DL: Immunohistochemical localisation of the creatine transporter in the rat brain. Neuroscience 2009, 163:571-585.

32. Stoll J, Wadhwani KC, Smith QR: Identification of the cationic amino acid transporter (systemy+) of the rat blood-brain barrier. J Neurochem 1993, 60:1956-1959.

33. Braissant O, Gotoh T, Loup M, Mori M, Bachmann C: L-arginine uptake, the citrulline-NO cycle and arginase II in the rat brain: an in situ hybridization study. Brain Res Mol Brain Res 1999, 70:231-241.

34. O'Kane RL, Viña JR, Simpson I, Zaragozá R, Mokashi A, Hawkins RA: Cationic amino acid transport across the blood-brain barrier is mediated exclusively by system y+. Am J Physiol Endocrinol Metab 2006, 291 E412-E419.
35. Hosoya K, Ichikawa T, Akanuma S, Hirose S, Tachikawa M: Glycine and Larginine transport in cultured Müller glial cells (TR-MUL). Neurochem Int 2010, 57:262-268.

36. Braissant $\mathrm{O}$, Béard E, Torrent $\mathrm{C}$, Henry H: Dissociation of AGAT, GAMT and SLC6A8 in CNS: Relevance to creatine deficiency syndromes. Neurobiol Dis 2010, 37:423-433.

37. Lunardi G, Parodi A, Perasso L, Pohvozcheva AV, Scarrone S, Adriano E, Florio T, Gandolfo C, Cupello A, Burov SV, Balestrino M: The creatine transporter mediates the uptake of creatine bybrain tissue, but not the uptake of two creatine-derived compounds. Neuroscience 2006, 142:991-997.

38. Tachikawa M, Kasai Y, Yokoyama R, Fujinawa J, Ganapathy V, Terasaki T, Hosoya K: The blood-brain barrier transport and cerebral distribution of guanidinoacetate in rats: involvement of creatine and taurine transporters. J Neurochem 2009, 111:499-509.

39. Ohtsuki S, Tachikawa M, Takanaga H, Shimizu H, Watanabe M, Hosoya K, Ohtsuki Terasaki T: The blood-brain barrier creatine transporter is a major pathway for supplying creatine to the brain. I Cereb Blood Flow Metab 2002, 22:1327-1335.

40. de Grauw TJ, Salomons GS, Cecil KM, Chuck G, Newmeyer A, Schapiro MB, Jakobs C: Congenital creatine transporter deficiency. Neuropediatrics 2002, 33:232-238.

41. Dechent P, Pouwels PJ, Wilken B, Hanefeld F, Frahm J: Increase of total creatine in human brain after oral supplementation of creatinemonohydrate. Am J Physiol 1999, 277:R698-R704.

42. Ipsiroglu OS, Stromberger C, llas J, Hoger H, Muhl A, Stockler-lpsiroglu S: Changes of tissue creatine concentrations upon oral supplementation of creatine-monohydrate in various animal species. Life Sci 2001, 69:1805-1815.

43. Perasso L, Cupello A, Lunardi GL, Principato C, Gandolfo C, Balestrino M: Kinetics of creatine in blood and brain after intraperitoneal injection in the rat. Brain Research 2003, 974:37-42.

44. Kan HE, Meeuwissen E, Veltien A, Isbrandt D, Heerschap A: Creatine uptake kinetics in brain and skeletal muscle of GAMT deficient knockout mice. Proc Intl Soc Mag Reson Med 2006, 14:1484.

45. Almeida LS, Verhoeven NM, Roos B, Valongo C, Cardoso ML, Vilarinho L, Salomons GS, Jakobs C: Creatine and guanidinoacetate: diagnostic markers for inborn errors in creatine biosynthesis and transport. Mol Genet Metab 2004, 82:214-219.

46. Skelton MR, Schaefer TL, Graham DL, Degrauw TJ, Clark JF, Williams MT, Vorhees CV: Creatine Transporter (CrT; Slc6a8) knocout mice as a model of human CrT deficiency. PloS One Jan 2011, 13:e16187.

doi:10.1186/1471-2202-13-41

Cite this article as: Carducci et al.: In vitro study of uptake and synthesis of creatine and its precursors by cerebellar granule cells and astrocytes suggests some hypotheses on the physiopathology of the inherited disorders of creatine metabolism. BMC Neuroscience 2012 13:41.

\section{Submit your next manuscript to BioMed Central and take full advantage of:}

- Convenient online submission

- Thorough peer review

- No space constraints or color figure charges

- Immediate publication on acceptance

- Inclusion in PubMed, CAS, Scopus and Google Scholar

- Research which is freely available for redistribution 